\title{
Pelatihan Blog Sebagai Media Komunikasi dan Penjualan Online Pada Warga RT 03 RW 02 Pondok Jati Jurangmangu Barat Pondok Aren Tangerang Selatan
}

\author{
Lis Suryadi ${ }^{*}$, Gandung Triyono ${ }^{2}$ \\ 1, 2, Fakultas Teknologi Informasi, Universitas Budi Luhur \\ ${ }^{1}$ lis.suryadi@budiluhur.ac.id, ${ }^{2}$ gandung.triyono@budiluhur.ac.id
}

\begin{abstract}
Abstrak
RT 02 RW o3 Pondok Jati Jurangmangu Barat Pondok Aren memiliki peranan besar dalam melayani dan melaksanakan pembangunan dalam rangka mengembangkan potensi dan sumber daya yang ada di lingkungan RT 02. Meskipun sebagian besar warga sudah menggunakan handphone untuk melakukan komunikasi, namun sebagian besar mereka belum maksimal dalam menggunakan perangkat teknologi informasi. Salah satu teknologi informasi yang banyak digunakan saat ini adalah web blog atau sering disebut blog. Selain digunakan sebagai media komunikasi dan dokumentasi, blog juga dapat digunakan sebagai media untuk melakukan penjualan produk secara online yang disebut dengan E-Commerce. Aplikasi berbasis web yang digunakan untuk memfasilitasi jual-beli yang dilakukan secara online disebut marketplace. Marketplace yang paling banyak digunakan saat ini adalah tokopedia, lazada, shopee, blibli dst. Adapun permasalahan yang dihadapi oleh RT 02 RT 03 Pondok Jati saat ini adalah kurangnya tenaga sumber daya manusia yang dimiliki pengetahuan dan keahlian dalam pemanfaatan teknologi informasi dan masih sedikitnya warga yang memanfaatkan teknologi informasi untuk menunjang kegiatan sehari-hari maupun untuk menunjang usaha/bisnis. Berdasarkan kondisi diatas, maka kami melaksanakan pelatihan membuat blog / marketplace. Dengan adanya pelatihan tersebut, maka warga di lingkungan RT 02 RT 03 Pondok Jati mampu membuat dan mengelola blog yang dapat digunakan sebagai media penjualan secara online dan untuk mendukung menyampaian informasi setiap kegiatan yang ada di lingkungan RT 02.
\end{abstract}

Kata Kunci: blog, media komunikasi, penjualan online, marketplace

\section{Pendahuluan}

Berdasarkan hasil wawancara dan survei yang telah kami lakukan, kami menemukan bahwa kondisi perekonomian warga di lingkungan RT 02 RT 03 Pondok Jati Jurangmangu Barat termasuk dalam golongan menengah ke bawah dan sebagian besar masyarakatnya bermata pencaharian sebagai pedagang dan pegawai swasta. Adapun jenis usaha yang berada di lingkungan RT 02 RT o3 Pondok Jati Jurangmangu Barat adalah warung, sewa rumah/kontrakan, percetakan, toko handphone/pulsa, pendidikan, bidan dan sewa kendaraan. Kondisi lainnya yang kami amati adalah politik dan sosial budaya, dimana pada warga RT 02 RT o3 Pondok Jati Jurangmangu Barat sangat terasa kebersamaan antar masyarakatnya, dilihat dari masih banyak diterapkannya metode 
permusyawaratan untuk mufakat untuk menyelesaikan masalah atau pengambilan keputusan terkait hal-hal yang menyangkut kepentingan warga. Selain itu kerukunan antar kampung juga masih terjaga dengan baik. Dari segi penggunaan perangkat teknologi informasi, sebagian besar warga di RT 02 RT o3 Pondok Jati Jurangmangu Barat ini sudah memiliki perangkat handpone untuk berkomunikasi. Namun penggunaannya hanya sebatas telepon, mengirim pesan singkat melalui aplikasi whatsapp atau mengupdate status melalui facebook atau istagram. Pemanfaatan perangkat teknologi informasi untuk penyampaian informasi berita di lingkungan RT 02 RT 03 Pondok Jati Jurangmangu Barat masih sangat jarang, bahkan penyampaian informsai masih dilakukan dari mulut ke mulut sehingga membutuhkan waktu yang lama agar informasi tersebut dapat diterima oleh seluruh warga di RT 02 RT 03 Pondok Jati Jurangmangu Barat RT 03 Pondok Jati Jurangmangu Barat. Sedangkan untuk dokumentasi kegiatan hanya disimpan melalui penyimpanan sementara melalui handphone, dimana dokumentasi tersebut akan rawan terhadap penghapusan dan kehilangan dokumentasi kegiatan yang dilakukan oleh RT 02 RT 03 Pondok Jati Jurangmangu Barat.

Berdasarkan kondisi diatas, maka kami berniat untuk melakukan penyuluhan dan pelatihan penggunaan perangkat teknologi informasi agar perangkat tersebut dapat dipergunakan secara maksimal untuk keperluan warga di lingkungan RT 02 RT 03 Pondok Jati Jurangmangu Barat. Permasalahan diatas menyebabkan penggunaan dan pemanfaatan teknologi informasi dan komunikasi kurang maksimal. Adapun solusi yang ditawarkan oleh tim pelaksana kegiatan pengabdian kepada masyarakat dapat dilihat pada Tabel 1.]

Tabel 1. Korelasi Masalah dengan Solusi yang ditawarkan

\begin{tabular}{lll}
\hline No. & Masalah & Solusi \\
\hline 1. & $\begin{array}{l}\text { Kurangnya pengetahuan dan } \\
\text { pemahaman mengenai tata cara } \\
\text { pembuatan blog. }\end{array}$ & $\begin{array}{l}\text { Mengadakan pelatihan mengenai } \\
\text { pembuatan blog. }\end{array}$ \\
\hline 2. & $\begin{array}{l}\text { Warga belum mengetahui cara } \\
\text { mengelola blog sebagai media } \\
\text { komunikasi, dokumentasi dan } \\
\text { mendukung usaha/bisnis. }\end{array}$ & $\begin{array}{l}\text { Mengadakan pelatihan mengenai } \\
\text { tata cara mengelola blog. }\end{array}$ \\
$\begin{array}{l}\text { Mengadakan pelatihan membuat } \\
\text { aplikasi E-Commerce. }\end{array}$ \\
\hline
\end{tabular}

Tujuan dari kegiatan pengabdian kepada masyarakat adalah memberikan pengetahuan dan wawasan kepada warga di lingkungan RT 02 RT 03 Pondok Jati Jurangmangu Pondok Aren mengenai manfaat teknologi blog di era digital dan memberikan pencerahan kepada warga RT 02 RT o3 Pondok Jati Jurangmangu Pondok Aren tentang cara pemanfaatan blog untuk menunjang kegiatan usaha/bisnis.

\section{Metode Pelaksanaan}

Flowchart berikut merupakan penjelasan mengenai metode pelaksanaan yang digunakan untuk menyelesaikan permasalahan yang terjadi di RT 02 RT 03 Pondok Jati Jurangmangu Pondok Aren. 


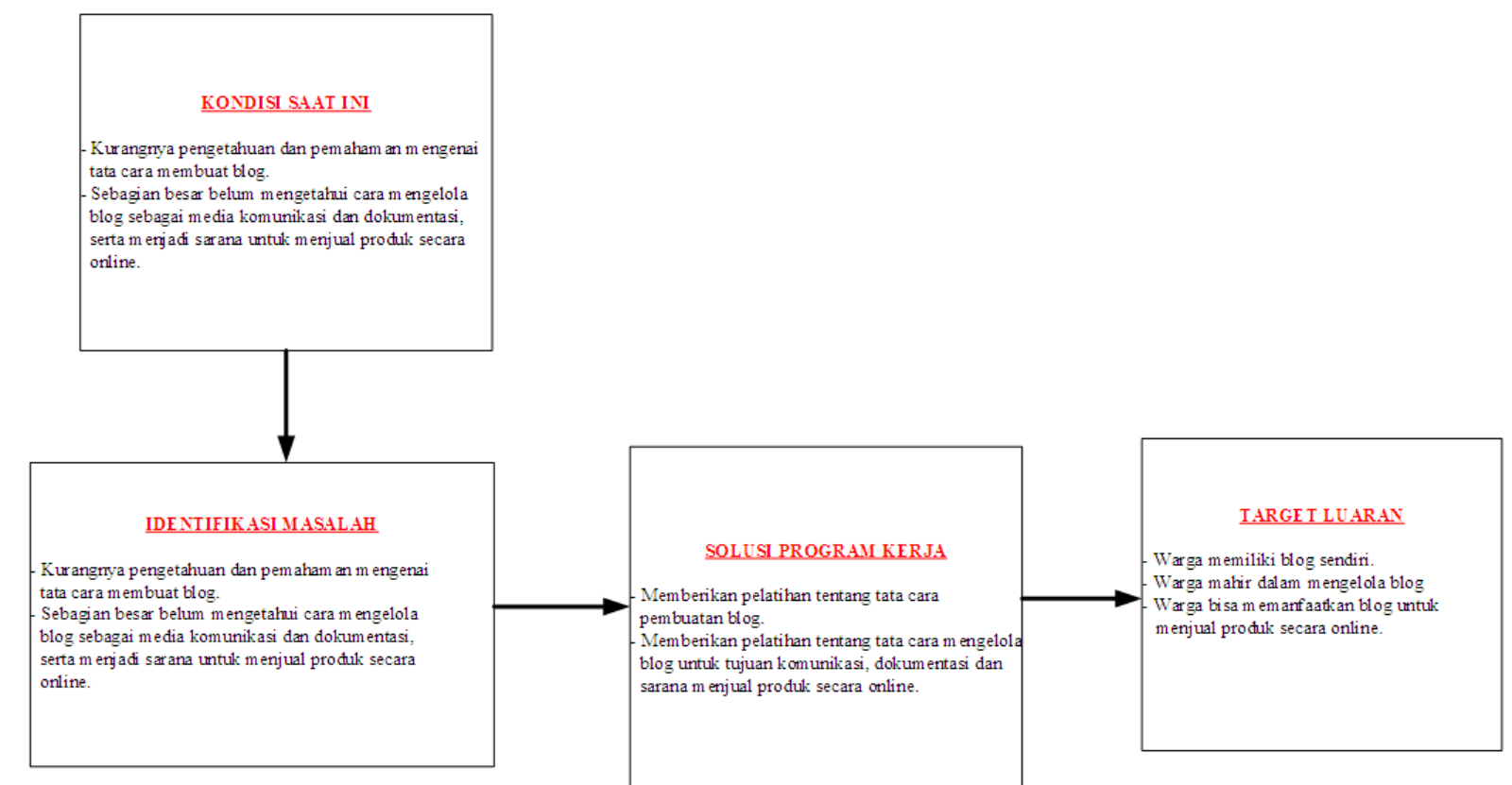

Gambar 1. Metode Pelaksanaan Kegiatan Pengabdian Kepada Masyarakat

Berikut ini adalah penjelasan singkat mengenai metode pelaksanaan untuk menyelesaikan permasalahan yang terjadi di RT 02 RT 03 Pondok Jati Jurangmangu Pondok Aren:

\section{Tahap analisis kondisi saat ini}

Di tahap ini, penulis melakukan analisis kondisi bisnis dan kondisi pemanfaatan perangkat teknologi informasi di RT o2 RT o3 Pondok Jati Jurangmangu Barat Pondok Aren dengan melakukan pengamatan langsung dan wawancara kepada ketua RT setempat.

\section{Tahap identifikasi permasalahan mitra}

Di tahap ini, penulis melakukan identifikasi masalah yang terjadi di RT o2 RT o3 Pondok Jati Jurangmangu Barat Pondok Aren, kemudian melakukan perumusan masalah.

\section{Tahap solusi program kerja}

Di tahap ini, penulis melakukan identifikasi solusi alternatif untuk menyelesaikan permasalahan dan menetapkan program kerja yang akan dilaksanakan.

\section{Tahap menetapkan target luaran.}

Di tahap ini, penulis melakukan penetapan target luaran yang akan dihasilkan dari kegiatan pengabdian kepada masyarakat ini.]

\section{Hasil dan Pembahasan}

Kegiatan pengabdian pada masyarakat bertema pelatihan pembuatan blog telah dilaksanakan pada hari sabtu, tanggal 15 Agustus 2020 yang dimulai pada pukul 10.30 sampai dengan 12.30 WIB menggunakan aplikasi Google Meet dengan alamat link: https://meet.google.com/amo-hsdu-dme dan diikuti oleh 15 (lima belas) orang warga pria dan wanita usia remaja di lingkungan RT o2 RT o3 Pondok Jati Jurangmangu Pondok Aren. 


\section{Madaniya \\ ISSN 2721-4834}

Menurut Herutomo (2010), blog adalah bentuk aplikasi web yang menyerupai tulisantulisan (yang dimuat sebagai posting) pada sebuah halaman web umum. Situs ini biasanya dapat diakses oleh semua pengguna internet sesuai dengan topik dan tujuan pengguna blog tersebut. Pembuatan blog ini bertujuan untuk membantu pengelola blog (atau yang disebut admin) untuk bisa berkomunikasi dengan pengguna blog. Menurut Hidayat (2008), E-Commerce atau toko online adalah suatu tindakan melakukan transaksi bisnis secara elektronik dengan menggunakan internet sebagai media komunikasi yang paling utama dan berhubungan dengan pembelian dan penjualan barang atau jasa melalui internet, khususnya World Wide Web (www).

Pelatihan pembuatan blog kali ini difokuskan pada pembuatan blog toko online menggunakan marketplace Tokopedia (http://tokopedia.com), dikarenakan kondisi yang tidak memungkinkan untuk melakukan praktikum di laboratorium komputer atau bertemu langsung selama musim pandemi Corona Virus 19 (Covid-19) yang belum berakhir. Gambar 2 merupakan pemaparan sambutan oleh Ketua Pelaksana Kegiatan Pengabdian Masyarakat Universitas Budi Luhur oleh Bapak Dr. Gandung Triyono, M.Kom. Dalam sambutannya, beliau mengucapkan terima kasih kepada peserta pelatihan yang telah menyempatkan waktu untuk mengikuti pelatihan yang diadakan oleh tim PKM dari Universitas Budi Luhur.]

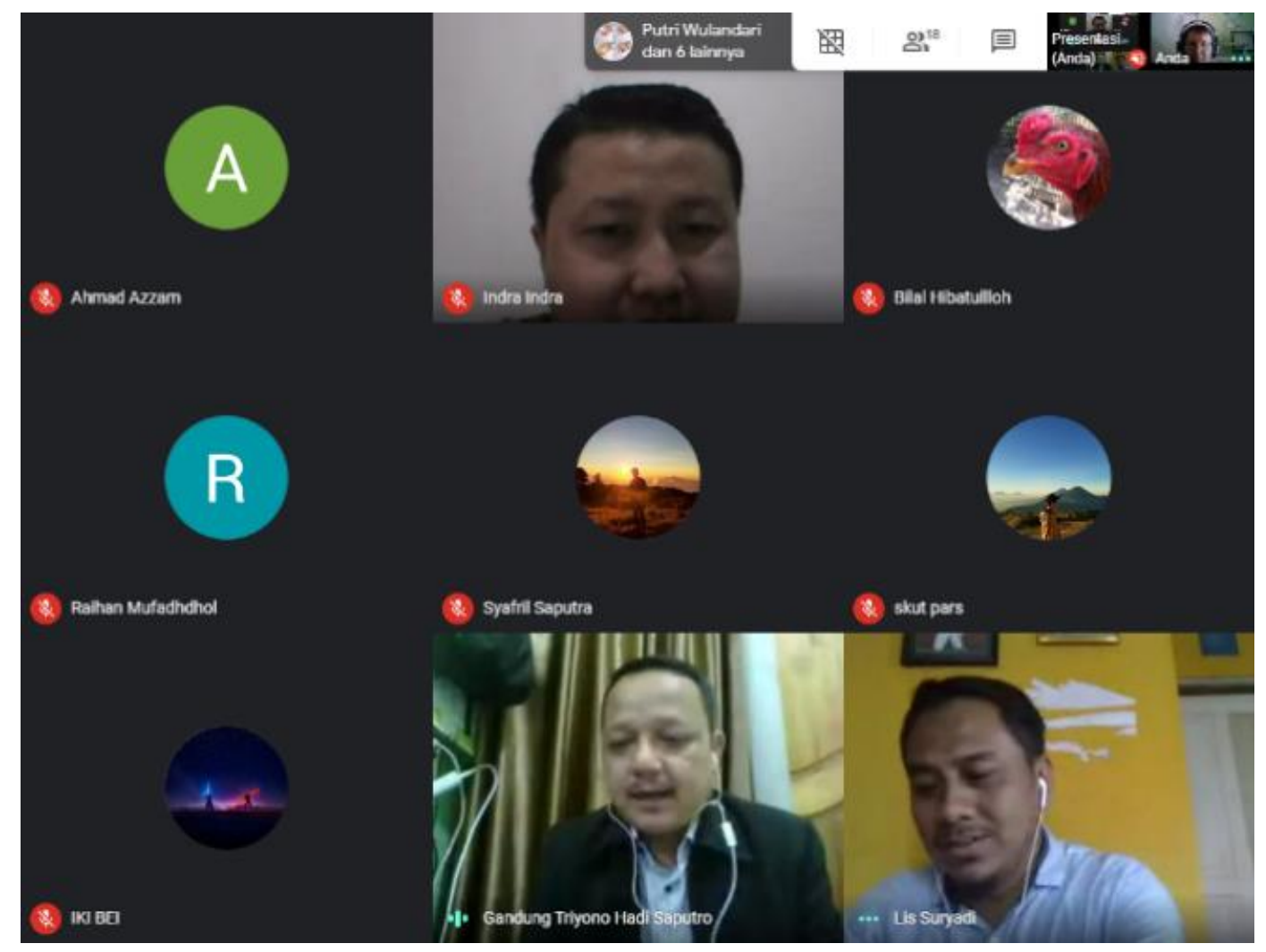

Gambar 2. Sambutan Ketua Pelaksana Kegiatan Pengabdian Masyarakat

Gambar 3 dan gambar 4 merupakan pemaparan materi pengantar / pengenalan blog, pengantar blog toko onlinesebagai media informasi dan komunikasi yang disampaikan oleh Bapak Lis Suryadi, M.Kom. Beliau menjelaskan bahwa pembuatan blog dilakukan menggunakan salah satu media pemasaran online atau marketplace dengan nama Tokopedia (http://tokopedia.com ). 
Vol. 2, No. 1, Februari 2021

ISSN 2721-4834

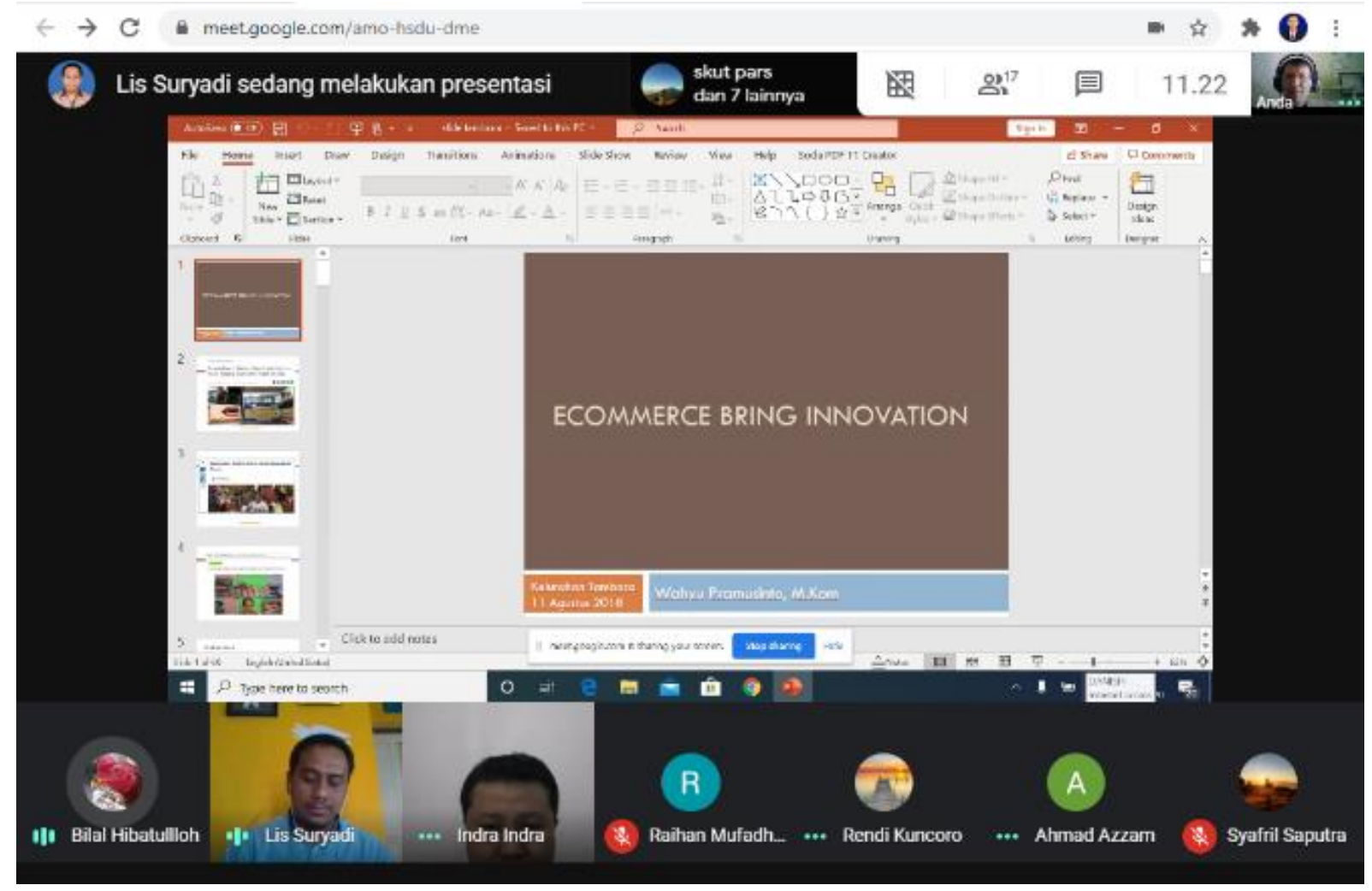

Gambar 3. Pemaparan Materi Pengantar Blog / E-Commerce

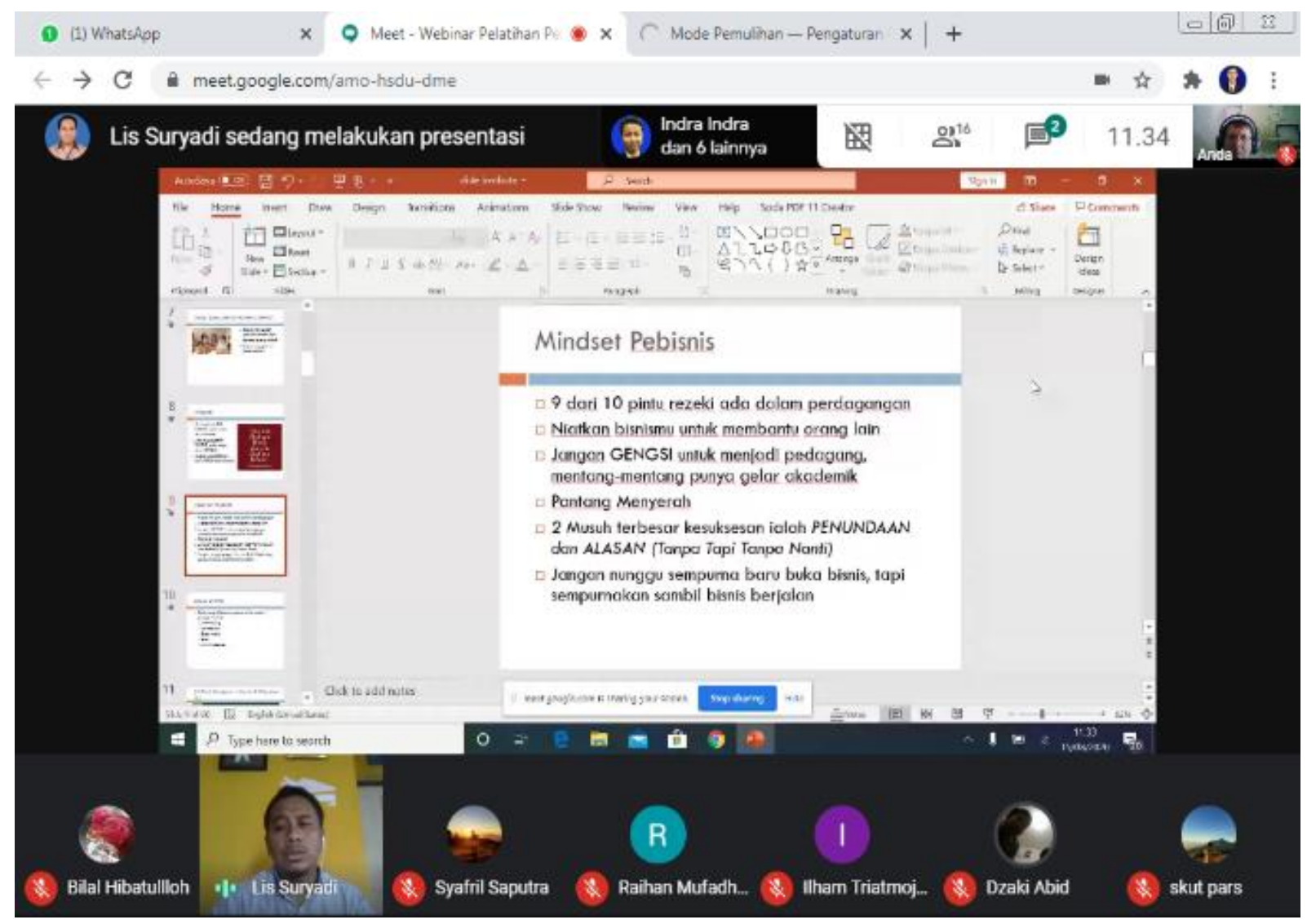

Gambar 4. Pemaparan Materi Pemanfaatan Blog Untuk Bisnis 
Gambar 5 merupakan dokumentasi pendaftaran nama blog toko online di marketplace Tokopedia. Peserta pelatihan diminta membuat nama toko online yang unik agar mudah diingat oleh tamu / pendatang. Pendaftaran blog pada marketplace Tokopedia (http://tokopedia.com) menggunakan akun Google Mail atau Akun Facebook milik peserta masing-masing.

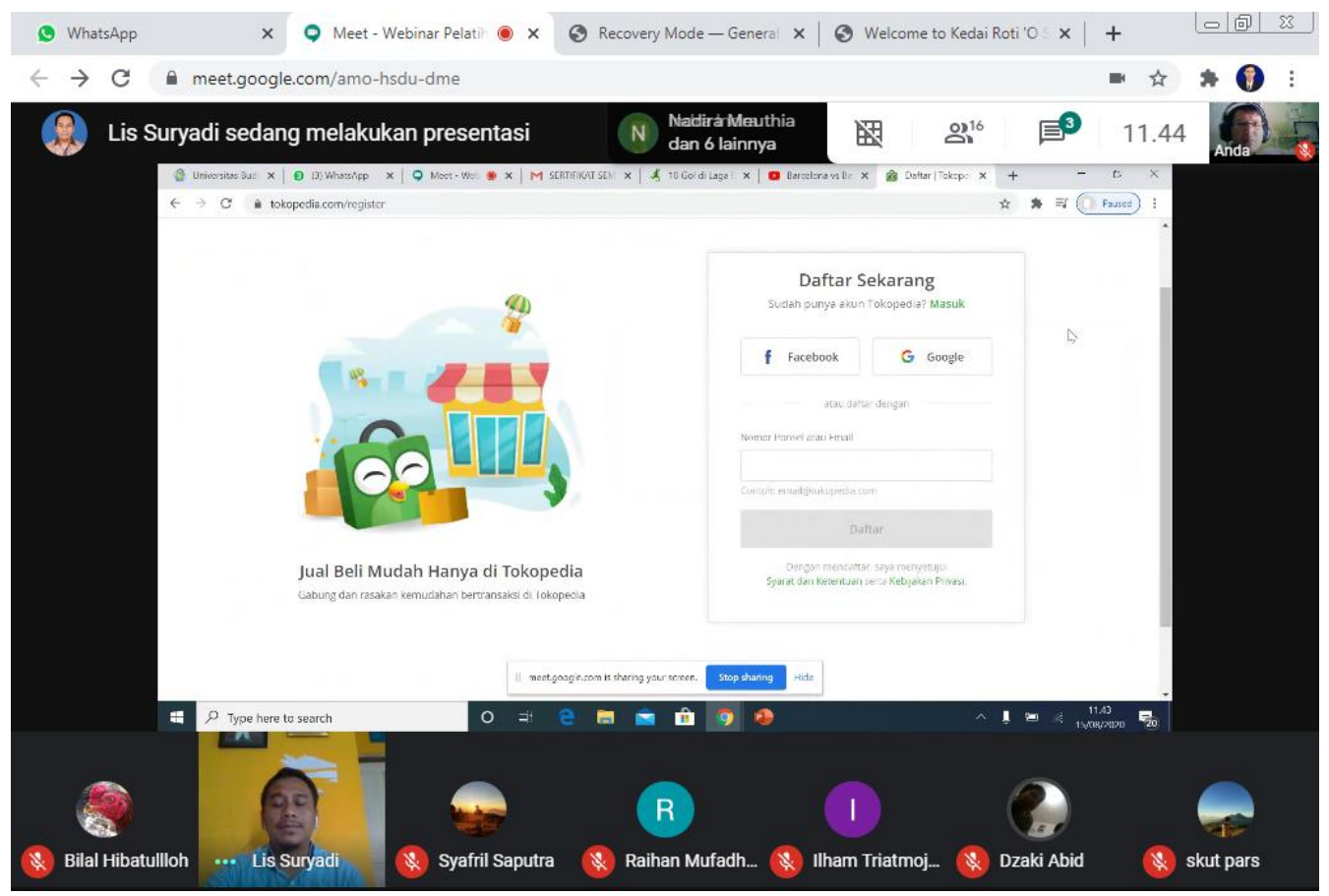

Gambar 5. Proses Pendaftarkan Toko Online

Gambar 6 merupakan alamat toko online yang sudah didaftarkan pada marketplace Tokopedia (http://tokopedia.com) dengan nama Bos Ikan Gabus dengan alamat URL https://www.tokopedia.com/lapak-ikan-gabus.

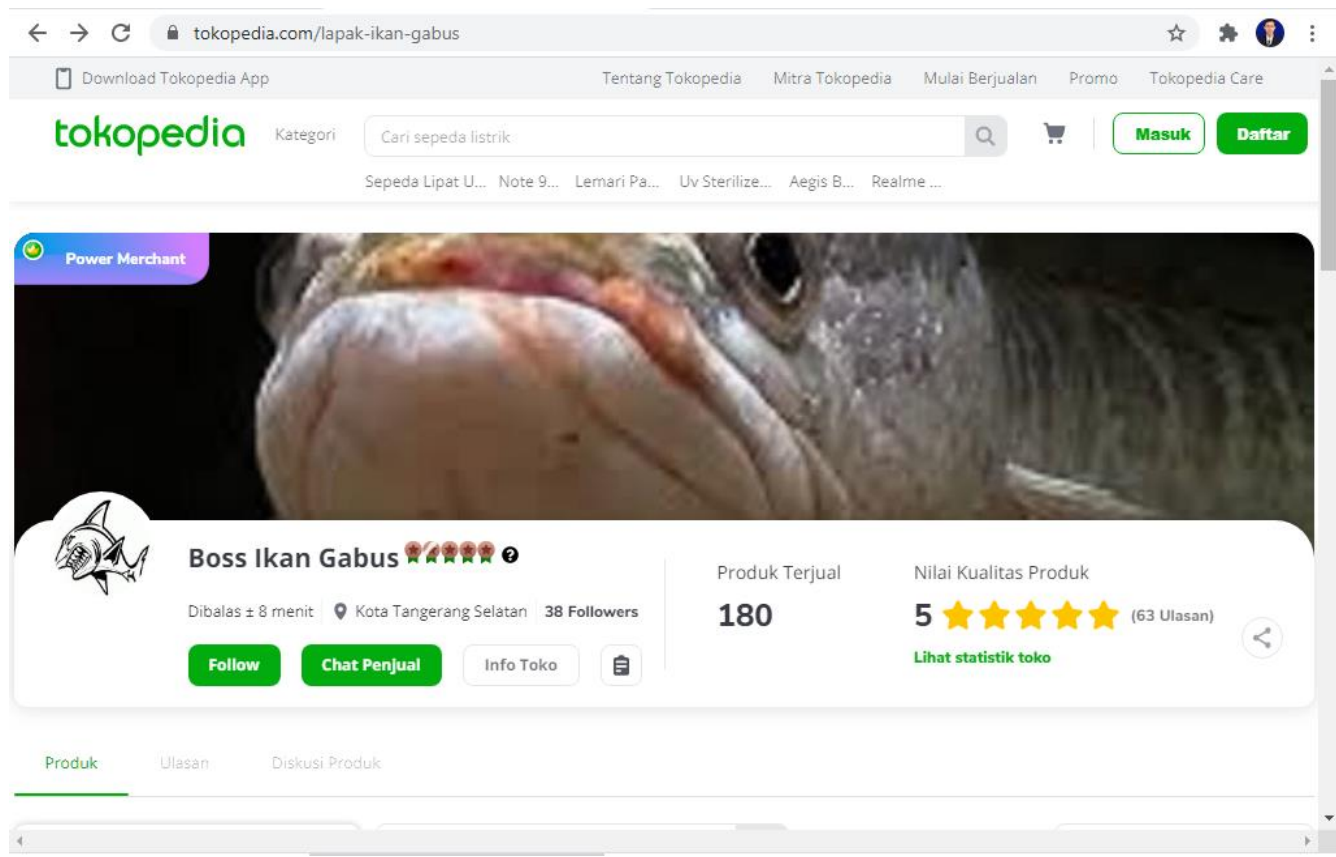

Gambar 6. Contoh Pemberian Nama Toko Online 
Vol. 2, No. 1, Februari 2021

ISSN 2721-4834

Gambar 7 dan gambar 8 merupakan dokumentasi penambahan katalog produk yang akan dijual pada blog toko online dan cara melihat detail saldo pendapatan yang diterima dari Tokopedia.

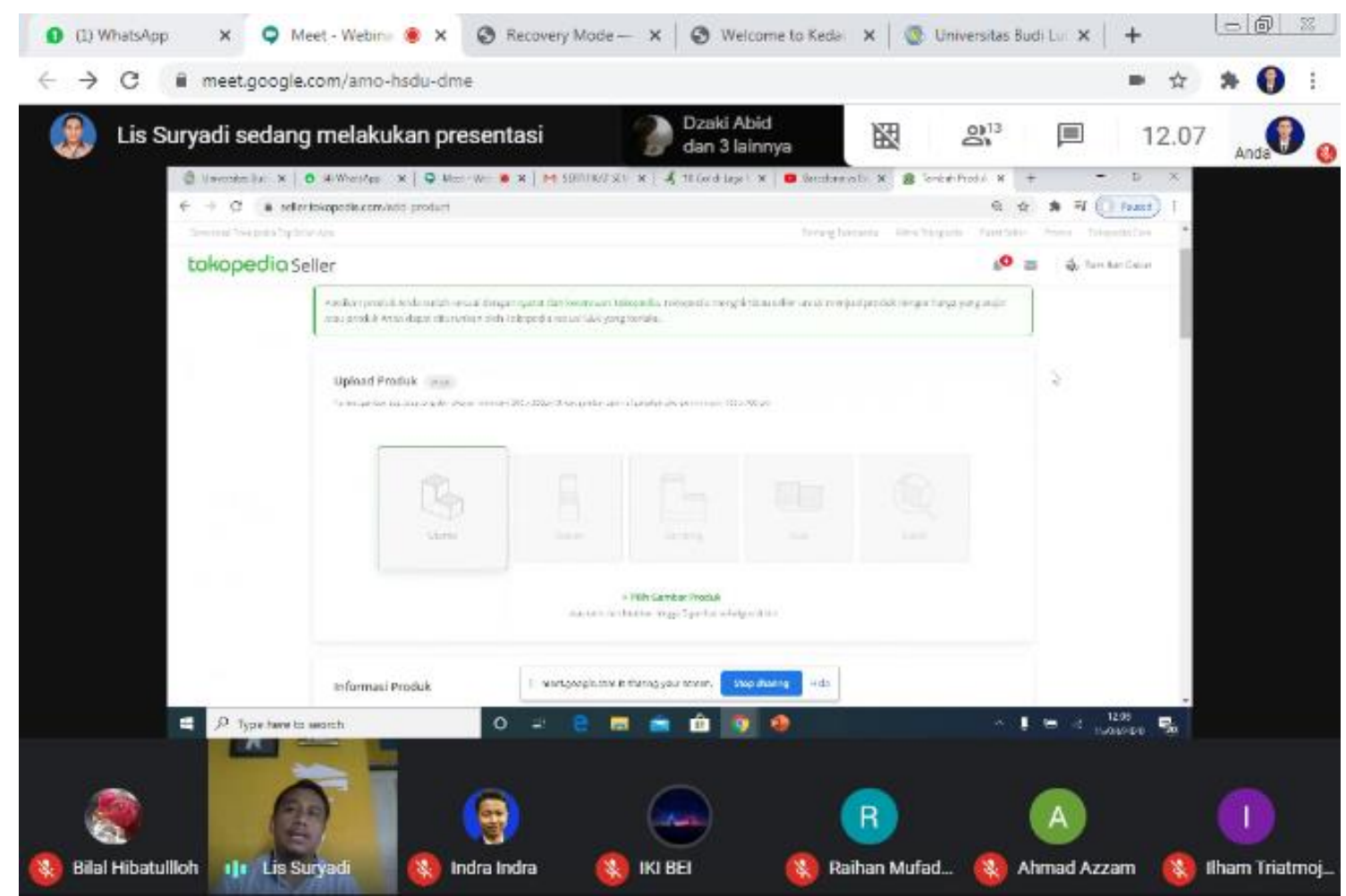

Gambar 7. Cara Mengupload Produk dan Melihat Detail Saldo

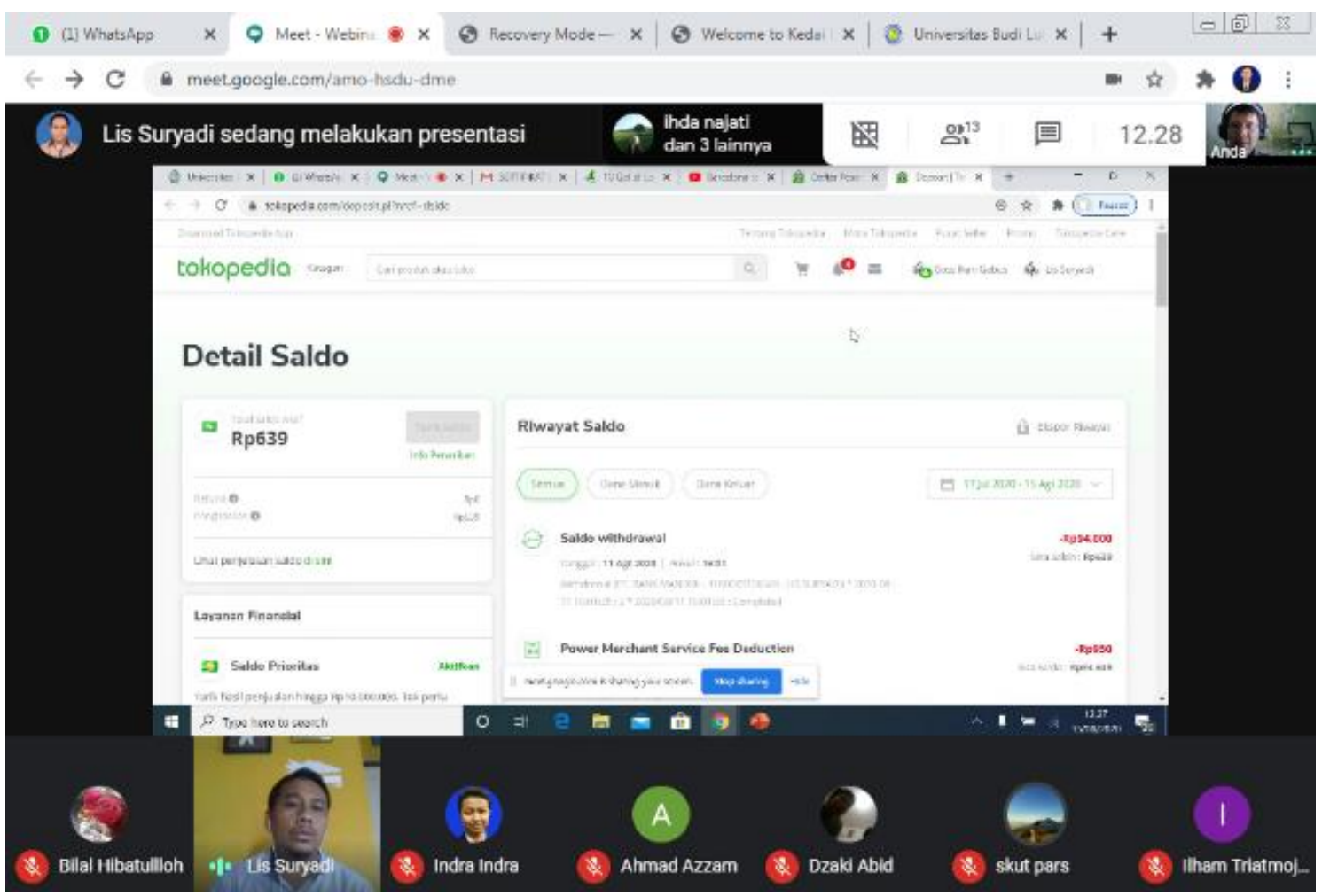

Gambar 8. Cara Melihat Detail Saldo 
Berikut ini adalah hasil rangkuman dari kegiatan pengabdian pada masyarakat di lingkungan RT o2 RT o3 Pondok Jati Jurangmangu Pondok Aren selama 1 (satu) hari tersebut dijelaskan pada tabel 2 berikut ini:

Tabel 2. Target Kegiatan dan Luaran Yang Dicapai

\begin{tabular}{lllll}
\hline No. & Materi & Nama Kegiatan & Target Kegiatan & Luaran Yang Dicapai \\
\hline $\begin{array}{llll}\text { 1. } \\
\text { Pembuatan } \\
\text { blog }\end{array}$ & $\begin{array}{l}\text { Melakukan pendaftaran } \\
\text { blog toko online di } \\
\text { marketplace Tokopedia } \\
\text { Membuat alamat URL } \\
\text { blog toko Online. }\end{array}$ & $\begin{array}{l}\text { Peserta dapat } \\
\text { memiliki blog / toko } \\
\text { online. }\end{array}$ & $\begin{array}{l}\text { Hampir 80\% peserta yang } \\
\text { mengikuti dan } \\
\text { mempraktekkan materi } \\
\text { dengan baik. }\end{array}$ \\
\hline $\begin{array}{l}\text { Mengelola } \\
\text { blog toko } \\
\text { online. }\end{array}$ & $\begin{array}{l}\text { Mengupload katalog } \\
\text { produk ke blog toko } \\
\text { online. }\end{array}$ & $\begin{array}{l}\text { Peserta dapat } \\
\text { menambahkan } \\
\text { produk-produk } \\
\text { yang dijual ke blog } \\
\text { toko online. }\end{array}$ & $\begin{array}{l}\text { Hampir 8o\% peserta dapat } \\
\text { mengikuti dan } \\
\text { mempraktekkan materi } \\
\text { dengan baik. }\end{array}$ \\
\hline 3. & Melihat riwayat saldo & pendapatan. & $\begin{array}{l}\text { Peserta dapat } \\
\text { bertanya melalui } \\
\text { forum tanya jawab. }\end{array}$ & $\begin{array}{l}\text { jumlah prosentase peserta } \\
\text { pelatihan yang bertanya } \\
\text { adalah 26,67\% dari total } \\
\text { peserta pelatihan }\end{array}$ \\
\hline
\end{tabular}

\section{Kesimpulan}

Dari pelaksanaan kegiatan dapat disimpulkan bahwa peserta pelatihan sangat antusias dan bersemangat mengikuti pelatihan pembuatan blog toko online tersebut, hal ini dapat dilihat dengan keseriusan peserta dalam melakukan praktikum mandiri di rumah secara daring (online), pelatihan pembuatan blog tersebut telah berjalan dengan baik sesuai dengan harapan dalam rangka meningkatkan kompetensi dan kreativitas peserta pelatihan dan peserta pelatihan dapat menggunakan pengetahuan dan kemampuan yang diperoleh dari pelatihan tersebut untuk mendukung kegiatan belajar, mendukung rutinitas kerja maupun pemanfatan lainnya.

\section{Ucapan Terimakasih}

\section{Referensi}

Denah Lokasi RT o2 RT o3 Pondok Jati Jurangmangu Barat Pondok Aren.

https://www.google.com/maps/search/rt+03+rw+02+pondok+jati+jurangmangu +barat/@-6.2617407,106.7122238,15z/data=!3m1!4b1 diakses pada 25 Mei 2020 pukul 8.50 WIB.

Herutomo, A. (2010). Conquering Web 2.0. Jakarta: PT. Elex Media Komputindo.

Hidayat, T. (2008). Panduan Membuat Toko Online dengan OS Commerce. Jakarta: Media Kita. 